\title{
Article \\ Corporate Governance from a Cross-Country Perspective and a Comparison with Romania
}

\author{
Bogdan Aurelian Mihail ${ }^{1, *}$ and Dalina Dumitrescu ${ }^{2}$ \\ 1 Doctoral School of Finance, Bucharest University of Economic Studies, 6 Piata Romana, \\ 010374 Bucharest, Romania \\ 2 Department of Finance, Bucharest University of Economic Studies, 6 Piata Romana, \\ 010374 Bucharest, Romania; dalina.dumitrescu@fin.ase.ro \\ * Correspondence: bog.mihail@gmail.com
}

check for

updates

Citation: Mihail, Bogdan Aurelian, and Dalina Dumitrescu. 2021.

Corporate Governance from a

Cross-Country Perspective and a

Comparison with Romania. Journal of Risk and Financial Management 14: 600 . https://doi.org/10.3390/

jrfm14120600

Academic Editor: Ştefan

Cristian Gherghina

Received: 8 November 2021

Accepted: 6 December 2021

Published: 13 December 2021

Publisher's Note: MDPI stays neutral with regard to jurisdictional claims in published maps and institutional affiliations.

Copyright: (c) 2021 by the authors. Licensee MDPI, Basel, Switzerland. This article is an open access article distributed under the terms and conditions of the Creative Commons Attribution (CC BY) license (https:// creativecommons.org/licenses/by/ $4.0 /)$.

\begin{abstract}
This paper investigates corporate governance from a cross-country perspective and makes a comparison with Romania. There are studies that examine the corporate governance issues related to Romanian companies, but these studies provide only qualitative and descriptive accounts of the research topic, with limited cross-country analysis. The present paper complements the literature by producing a quantitative analysis of cross-country corporate governance and makes a comparison with Romania. For this purpose, a set of corporate governance indicators from a large sample of 39 advanced and developing countries was collected for the 2006-2020 period. In terms of corporate governance dimensions, it was found that Romania underperforms other developing countries in the dimensions of director liability and ownership and control, while it outperforms them in the dimensions of corporate transparency, disclosure, and shareholder rights. The results indicate that the stagnant corporate governance scores and the low development level of stock markets stand out as important business challenges for the country. The correlation and regression analyses show that stock market development is closely associated with corporate governance dimensions and, overall, corporate governance scores matter greatly for the economic growth of countries, such as Romania, which can benefit greatly from the improvement of corporate governance codes and practices in the private sector.
\end{abstract}

Keywords: corporate governance; Romania; protection of minority investors; stock market development; economic growth

\section{Introduction}

Corporate governance matters greatly for the efficiency of different business sectors in various countries (Belloc 2012; Donaldson 2013). Modern corporations are generally large and very complex organisations. As their management by owners would not be very feasible or efficient, the corporations hire professional managers to run their companies on the behalf of owners and shareholders. This separation of ownership and control becomes a leading characteristic of modern corporations. However, as the agency theory shows, due to asymmetric information and costly state verification problems, managers can follow their own interests at the expense of the shareholders. Various corporate governance mechanisms were developed to address these problems and improve the efficiency of corporations (Misangyi and Acharya 2014; Tihanyi et al. 2014). It can be argued that corporate governance is not just a micro or firm-specific topic. In contrast, the quality of corporate governance can matter greatly for stock market development and economic growth of countries (Classens 2006; Claessens and Yurtoglu 2012). As a result, conducting cross-country analyses of corporate governance indicators is an important research discussion topic, with major business and policy implications.

The literature has studies examining the issue of corporate governance from an international perspective. For example, Khanna et al. (2006) investigated whether globalisation 
is instrumental in the convergence of corporate governance standards across countries and found supportive evidence. However, Doidge et al. (2007) noted that there are still larger differences in corporate governance scores (such as investor protection) of countries. Aguilera and Jackson (2010) worked on a very detailed review study that conducted a comparative cross-country analysis of corporate governance. The authors concluded that the differences in the corporate governance practices and scores can be explained by various factors, such as managerial factors, social and cultural factors, political factors, and institutional factors. Hence, this study is important for the present paper in the sense that it provides a rationale for the comparison of corporate governance scores in Romania to other developing and advanced countries. In another review paper, Claessens and Yurtoglu (2013) provided a comparative analysis of corporate governance in emerging countries. The authors showed that the improvement of corporate governance can affect firm performance positively; however, when the corporate governance score of the country is low, this positivity weakens. In another study, Aggarwal et al. (2007) compared the corporate governance quality of US firms to international firms. The authors found that the US firms outperform foreign firms on average and effect the markets value board and audit committee independence positively. Overall, these studies show that examining corporate governance issues from a cross-country perspective and making comparisons with individual country cases can provide valuable findings on the relevant topics, with important business and policy implications. In this context, the present paper aims to make a comparative analysis of the case of Romania in terms of corporate governance scores.

There are already studies that examine the topic of corporate governance in Romania, its evolution over time, the challenges facing the corporate governance system in the countries, and its comparison to other countries (Badulescu 2008; Sarchizian and Popovici 2019; Tofan and Cigu 2020). These studies generally provide very detailed descriptive and qualitative accounts, whereas the present paper complements them by providing a comparison with other countries. Bussu (2015) notes that Romania has been following the OECD general principles and the EU directives in terms of corporate governance. While the rules and regulations are similar to the international best standards, the country had some challenges in terms of efficient applications of them. For example, on the dimensions of disclosure, transparency, the rights of shareholders, and the responsibilities of the board, Romania performs very poorly relative to the international standards. Shortcomings in the implementation of corporate governance best practices are also acknowledged in other studies (Manolescu et al. 2011; Grosu 2011; Feleagă et al. 2011). Overall, existing literature on Romanian corporate governance provides detailed accounts of its evolution and challenges. However, a quantitative comparison of the Romanian case relative to other countries is not provided in the literature. The present paper fills this research gap by conducting a quantitative analysis of various corporate governance dimensions in a cross-country setting and displaying the importance of corporate governance quality for stock market development and economic growth of countries. For this purpose, a large sample of 39 advanced and developing countries (including Romania) was collected from the World Bank (2021). The quantitative results indicate that Romania has a relatively low corporate governance score and, more importantly, displayed very limited improvement relative to other countries. In addition, regression findings show that stock market development is closely associated with corporate governance dimensions and overall corporate governance score matters greatly for the economic growth of countries. Based on these results, it can be argued that Romania can benefit greatly in terms of stock market development and economic growth by improving its corporate governance standards and implementation. The paper is structured as follows. The next section presents the data and research methods utilised in the study, while the third section presents the empirical results. Finally, the last section concludes the paper. 


\section{Data and Research Methods}

The research topic in this paper is the role of corporate governance and its implications for economic growth and stock market development in a cross-country setting. Romania is a developing country, and the level of stock market development is relatively limited compared to other developing, as well as advanced, countries. There can be various factors leading to this limited development, but examining all of the possible factors and mechanisms is in the scope of the present study. In this context, the paper focuses on the corporate governance dimension as an important factor in affecting stock market development and economic growth. Corporate governance is a broad topic that focuses on the efficient management of the business world regarding the improvement of financial performance and alleviating conflicts of interest in modern corporations (Becht et al. 2003; Bebchuk et al. 2009; Larcker and Tayan 2015). In order to assess these relationships and effects, one can use existing public datasets, such as the OECD Corporate Governance Factbook (OECD 2021). This dataset is very comprehensive and includes detailed information about the corporate governance practices of 50 countries. However, for the purpose of the present paper, a major limitation is that it does not include Romania in the sample. This data availability issue puts a binding constraint on the possible quantitative analysis that the paper can conduct. A public dataset that has information on corporate governance dimensions for Romania is the Doing Business database of the World Bank (2021). This index has information on various dimensions of the business environment in countries. One of these dimensions is the protection of minority rights. This dimension is assessed in the context of the stock markets (the Bucharest Stock Exchange), in the case of Romania, and includes the following items: the conflict of interest regulation, the extent of disclosure, the extent of director liability, the extent of shareholder suits, the shareholder governance, the extent of shareholder governance rights, the extent of ownership and control (which includes sub-items like the CEO duality and independent board members), and the extent of corporate transparency. While these items were examined under the dimension of protecting minority rights, it is seen that they provide detailed information on some corporate governance dimensions, such as CEO duality (Elsayed 2007; Krause et al. 2014), independent board members (Fernandes 2008; Cavaco et al. 2017), non-executive board members (Young 2000; Basco et al. 2019), financial reporting (Lee 2007; Ong 2018), and external auditing (Baker and Owsen 2002; Mennicken and Power 2013) and transparency about management compensation. The corporate governance literature shows that these are very important factors affecting business outcomes and financial performance (Bhagat and Bolton 2008, 2019). Based on this vast literature, the data from the World Bank (2021) are utilised descriptively and quantitatively to make a comparison of corporate governance in Romania with other developing and advanced countries. This variable on the protection of minority investors and its sub-components is presented in Table 1.

In Table 1, the protection of minority investors is the main independent variable that the present paper is interested in. The other variables in the table are the components of this protection variable. All of these variables in Table 1 were used in the descriptive analysis to compare the case of Romania with other developing and advanced countries. Including all of them in the regression analysis would cause multicollinearity issues (because the correlation coefficients are very high among the components); hence, only the protection of minority investors was added into the regression analysis as the main independent variable. 
Table 1. Corporate governance: Variable names and definitions (World Bank 2021).

\begin{tabular}{ll}
\hline Variable & Definition \\
\hline Protecting Minority Investors & $\begin{array}{l}\text { The score for protecting minority investor benchmark } \\
\text { economies, with respect to the regulatory best practice on the } \\
\text { indicator set. }\end{array}$ \\
\hline Corporate Transparency & $\begin{array}{l}\text { The extent of the corporate transparency index measures ans } \\
\text { the level of information that companies must share. }\end{array}$ \\
\hline Director Liability & $\begin{array}{l}\text { The extent of the director liability index measures when board } \\
\text { members can be held liable for harm caused by related-party } \\
\text { transactions and which sanctions are available. }\end{array}$ \\
\hline Disclosure & $\begin{array}{l}\text { The extent of the disclosure index measures the approval and } \\
\text { disclosure requirements of related-party transactions. }\end{array}$ \\
\hline Ownership and Control & $\begin{array}{l}\text { The extent of ownership and control index measures the rules } \\
\text { governing the structure and change in control of companies. }\end{array}$ \\
\hline Shareholder Rights & $\begin{array}{l}\text { The extent of the shareholder rights index measures the role } \\
\text { of shareholders in key corporate decisions. }\end{array}$ \\
\hline Source: World Bank (2021). &
\end{tabular}

With reference to the methodological approach of examining the given variables, two methods were followed. The first method waws to provide a descriptive analysis of the data for Romania and compare the relevant indicators with other developing and advanced countries. For this comparison, a list of 39 countries (13 developing countries including Romania and 26 advanced countries) was collected from the World Bank (2021). These countries were Romania, Albania, Australia, Austria, Belgium, Brazil, Bulgaria, Canada, Chile, Croatia, Czechia, Denmark, Finland, France, Germany, Greece, Hungary, Ireland, Italy, Japan, Korea, Malaysia, Mexico, Netherlands, New Zealand, Norway, Poland, Portugal, Russia, Singapore, Slovak Republic, Slovenia, South Africa, Spain, Sweden, Thailand, Turkey, the UK, and the US. The sample period covered the years from 2006 to 2020 due to data availability. In the descriptive analysis, the evolution of the stock market development and corporate governance indicators were presented in relation to the other countries. In addition, the summary statistics were compared between Romania and other countries, and the relative position of corporate governance in Romania was displayed for the last 2 decades. The second method in the paper was regression analysis of the cross-country data. The paper argues that corporate governance matters because it supports stock market development, and in return, stock market development supports the economic development of countries. In order to check these mechanisms, a growth regression framework was followed (Barro 1991, 2003), where the dependent variable of the GDP growth was predicted using the independent variables of stock market capitalisation ratio and the protection of minority investors, along with some control variables. In terms of the control variables, the growth literature was utilised to select the following variables: investments (Iwaisako and Futagami 2013), savings (Mohan 2006), international trade (Singh 2010), foreign direct investments (FDI) (Chowdhury and Mavrotas 2006), private credit (Law and Singh 2014), and stock market capitalisation (Cooray 2010). In addition, the literature also shows that corporate governance can be an important factor contributing to economic growth (Classens 2006; Claessens and Yurtoglu 2012). As a result, the protection of minority investors was added as the main independent variable. In this context, the relevant regression model was formulated as follows:

$\begin{aligned} \text { GDP Growth }_{i, t}= & \beta_{0}+\beta_{1} \text { Investments }_{i, t}+\beta_{2} \text { Savings }_{i, t}+\beta_{3} \text { Trade }_{i, t}+\beta_{4} F_{D I} I_{i, t}+\beta_{5} \text { Private }_{\text {Credit }}, t \\ & +\beta_{6} \text { Stock Market Capitalisation }_{i, t}+\beta_{7} \text { Protection of Minority Investors }_{i, t}+\varepsilon_{i, t}\end{aligned}$

In the above equation, $i$ refers to the country and $t$ refers to the year. The control variables of investments, savings, trade, FDI, private credit, and stock market capitalisation are all represented as ratios to GDP in order to make them comparable across countries. 
The main variable of interest becomes the protection of minority rights, which can be considered as a leading corporate governance indicator for countries. The regression models were estimated using the ordinary least squares (OLS) and fixed-effects (FE) regression methods (Wooldridge 2010). The OLS results were presented as the benchmark findings, while the FE results were expected to provide more robust findings since they controlled the unobserved country fixed (i.e., time-invariant) effects in the regressions.

Overall, based on the above discussions, the two working hypotheses of the empirical analysis are stated as follows:

Hypothesis 1. Corporate governance is positively associated with stock market development.

Hypothesis 2. Corporate governance is positively associated with economic growth rates.

\section{Results}

This section presents the results of the paper. As discussed above, the results are presented in two parts. The first part provides a descriptive analysis of the corporate governance developments in Romania, with a cross-country perspective. The second part presents the results of the regression analysis in order to document the association of corporate governance with economic growth.

\subsection{Descriptive Analysis}

This part presents a descriptive analysis of the corporate governance dimensions for the case of Romania, with a cross-country perspective. The variable definitions provided in Table 1 show that there are various dimensions of corporate governance in the given dataset, including corporate transparency, director liability, disclosure, ownership and control, and shareholders' rights. These indicators were combined under the aggregate index of the protection of minority investors (World Bank 2021). One can use this aggregate index as a proxy for the quality of corporate governance practices in countries. In this context, Figure 1a,b presents the evolution of the average scores for the extent of the minority investor protection in the developing and advanced countries, respectively.

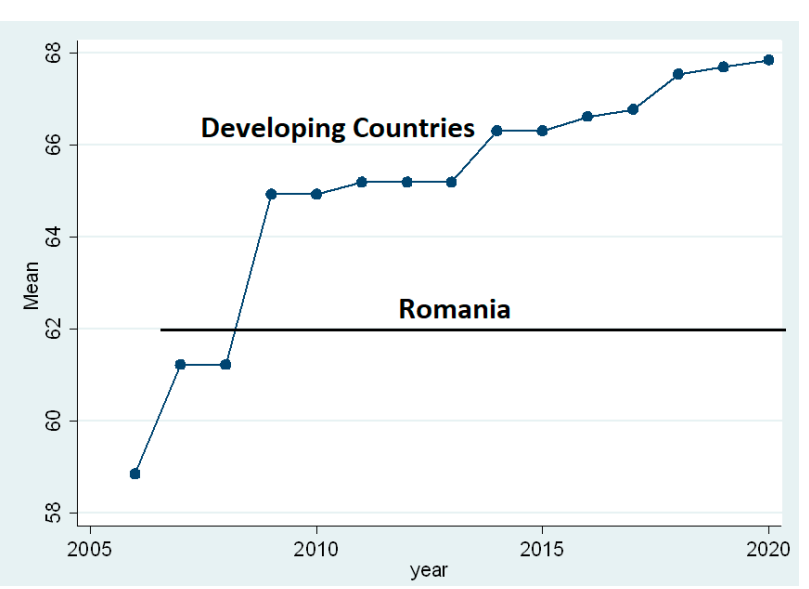

(a)

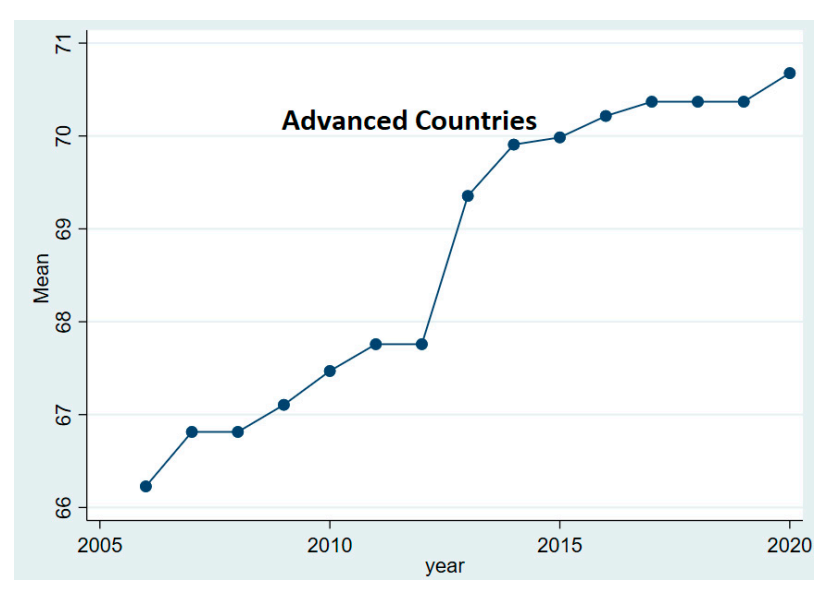

(b)

Figure 1. The average score for the extent of minority investor protection. (a) Developing countries and Romania; (b) advanced countries.

It can be seen in Figure $1 \mathrm{~b}$ that the average corporate governance score for the developing countries displayed an upward trend in the last couple of decades. It increased from around 59 in 2006 to 68 in 2020, out of a maximum score of 100. Interestingly, Romania had a corporate governance score above the average of the developing countries initially. However, as the country did not display any increase in its governance score since 2007, it lagged behind other developing countries since 2009. Given the rising difference in 
corporate governance scores between Romania and other developing countries, it can be argued that the country has a relatively poor corporate governance framework compared to other developing countries. As a result, this difference and corresponding relatively poor performance become important policy areas for businesses and the stock market in Romania. When the performance of the advanced countries is examined in panel (b) of Figure 1, it can be seen that these countries also displayed an upward trend in their corporate governance scores during the last couple of decades. Namely, the average governance score for the advanced countries increased from 66 in 2006 to 71 in 2020. These numbers imply that the average corporate governance score has been persistently above in advanced countries compared to developing countries.

In addition to the above two graphs, providing detailed summary statistics for the overall score of minority investors protection and its components would be informative to get a deeper understanding of Romania's relative performance in corporate governance dimensions. In this context, Table 2 presents the summary statistics of the overall index of minority investor protection and its five components (i.e., corporate transparency, director liability, disclosure, ownership and control, and shareholders rights). The results are presented in three panels, i.e., the summary statistics for Romania in Panel A, the summary statistics for Developing Countries in Panel B and the summary statistics for Advanced Countries in Panel C.

Table 2. Summary statistics.

\begin{tabular}{|c|c|c|c|c|c|}
\hline \multicolumn{6}{|c|}{ A: Descriptive Statistics-Romania } \\
\hline Variable & Obs & Mean & Std. Dev. & Min & Max \\
\hline Protection of Minority Investors & 15 & 61.752 & 0.96 & 58.282 & 62 \\
\hline Corporate Transparency & 7 & 71.429 & 0 & 71.429 & 71.429 \\
\hline Director Liability & 15 & 40 & 0 & 40 & 40 \\
\hline Disclosure & 15 & 89.333 & 2.582 & 80 & 90 \\
\hline Ownership and Control & 7 & 42.857 & 0 & 42.857 & 42.857 \\
\hline Shareholder Rights & 7 & 83.333 & 0 & 83.333 & 83.333 \\
\hline \multicolumn{6}{|c|}{ B: Descriptive Statistics-Developing Countries } \\
\hline Variable & Obs & Mean & Std. Dev. & Min & Max \\
\hline Protection of Minority Investors & 180 & 65.328 & 13.371 & 13.98 & 88 \\
\hline Corporate Transparency & 84 & 67.347 & 28.013 & 0 & 100 \\
\hline Director Liability & 180 & 52.167 & 24.728 & 0 & 90 \\
\hline Disclosure & 180 & 73.833 & 24.638 & 0 & 100 \\
\hline Ownership and Control & 84 & 63.605 & 22.659 & 0 & 85.714 \\
\hline Shareholder Rights & 84 & 75.595 & 26.567 & 0 & 100 \\
\hline \multicolumn{6}{|c|}{ C: Descriptive Statistics-Advanced Countries } \\
\hline Variable & Obs & Mean & Std. Dev. & Min & Max \\
\hline Protection of Minority Investors & 390 & 68.746 & 9.693 & 36.023 & 86 \\
\hline Corporate Transparency & 182 & 81.538 & 11.63 & 57.143 & 100 \\
\hline Director Liability & 390 & 56.59 & 19.545 & 20 & 90 \\
\hline Disclosure & 390 & 65.077 & 23.672 & 10 & 100 \\
\hline Ownership and Control & 182 & 67.881 & 19.426 & 28.571 & 100 \\
\hline Shareholder Rights & 182 & 78.48 & 14.946 & 33.333 & 100 \\
\hline
\end{tabular}

When the summary statistics for Romania, developing countries, and advanced countries are examined, some important data properties and cross-country differences can be identified. The upper panel of Table 2 shows that the average score for the protection of minority investors in Romania was 61.752, with a standard deviation of 0.96 , during the 2006-2020 period. A closer examination of this corporate governance index reveals that Romania had a score of 58.282 in 2006, which increased to 62 in 2007 and stayed constant at this level for the rest of the sample. Hence, there was a one-time improvement in this score, with no change for the 2007-2020 period. In the case of the corporate transparency index, the average score was 71.429, with a standard deviation of 0 . The zero value for the 
standard deviation implies that the score for these corporate governance dimensions did not vary during the sample period. In fact, it is seen that there were only seven observations in this case. Hence, the short sample period is an important data constraint avoiding the conduct of quantitative analysis, such as regression models in the case of individual countries. In the case of the director liability dimension, Romania had a mean score of 40 , which also did not vary over the sample period. The first panel of Table 1 shows that the average disclosure score was 89.333, with a standard deviation of 2.582. The table shows that this variable increased from 80 to 90 , displaying a large improvement in the relevant corporate governance dimension. In addition, the disclosure dimension was the component of corporate governance with the highest score in Romania. In contrast, in case of the ownership and control dimension, it had a very low score of 42.857 in the sample period, showing the poor performance of the country on this important dimension. Lastly, in the dimension of shareholder rights, the average score was estimated as 83.333, which is one of the high-scored components of corporate governance in Romania.

When the corporate governance scores for the developing countries in the sample are examined in the second panel of Table 2, the wide variation in the data stands out, showing the high level of heterogeneity among these countries. It is seen that the average score of corporate governance (as measured by the variable of minority investor protection) is estimated as 65.328, with a standard deviation of 13.371. Therefore, the average of the developing countries is larger than the corporate governance score of Romania. Additionally, there is great variation in this variable, with a minimum value of 13.98 and a maximum value of 88 . Hence, the position of Romania can be considered below but close to the mean of developing countries. In the corporate transparency dimension, the average value was estimated as 67.347, with a standard deviation of 28.013. This variable ranged from 0 to 100, showing the wide dispersion in the data. Romania had a higher score with 71.429 in corporate transparency compared to the other developing countries. In the director liability dimension, the average value for developing countries was estimated as 52.167 , with a standard deviation of 24.728. This variable ranged from 0 to 90 , again showing the wide dispersion in the data. In this case, the performance of Romania was poorer with a score of 40 compared to the other developing countries. In the case of the disclosure dimension, the average value for the developing countries was estimated as 73.833 , with a standard deviation of 24.638. This variable also ranged from 0 to 100, showing the wide dispersion in the data. Romania had a higher score with 89.333 in the disclosure dimension compared to the other developing countries. In the case of ownership and control dimension, the average value for developing countries was estimated as 63.605, with a standard deviation of 22.659. This variable ranged from 0 to 85.714 , showing the wide dispersion in the data. In this case, Romania had poorer performance with a score of 42.857 compared to the other developing countries. Finally, in the shareholder rights dimension, the average value was estimated as 75.595, with a standard deviation of 26.567. This variable ranged from 0 to 100 , showing the wide dispersion in the data. In this case, Romania had a higher score with 83.333 compared to the other developing countries. Overall, the general corporate governance score of Romania was below but very close to the average of other developing countries. In addition, Romania underperformed other developing countries in the dimensions of director liability and ownership and control while it outperformed them in the dimensions of corporate transparency, disclosure, and shareholder rights. Therefore, Romania had a mixed performance relative to the other developing countries, and as is shown in Figure 1, while other developing countries displayed a persistent improvement in their corporate governance scores, Romania maintained a stagnant outlook.

The last panel of Table 2 shows the summary statistics of corporate governance indicators in the case of the advanced countries in the sample. It is seen that the average corporate governance score was estimated as 68.746, with a standard deviation of 9.693. This value was larger than the average in developing countries and Romania. With reference to the corporate governance dimensions, it is seen that the advanced countries had the largest average scores for corporate transparency and shareholder rights, with values of 81.538 and 
78.48 , respectively. In contrast, the dimensions of disclosure and ownership and control had lower average scores, with values of 65.077 and 67.881, respectively. Finally, the corporate governance dimension with the lowest score for the advanced countries was the director liability, with a value of 56.59. When the average scores for the corporate governance dimensions are compared, it can be found that the advanced countries had larger mean values than the developing countries in all dimensions, except for the disclosure dimension. Overall, Table 2 provides valuable descriptive information about the relative performance of Romania in various corporate governance dimensions compared to other developing countries. The next part of this section conducts a quantitative analysis in order to see how corporate governance is connected to stock market development and economic growth.

\subsection{Regression Analysis}

The previous part of this section provided a detailed comparison of the corporate governance indicators for Romania in a cross-country setting relative to a large sample of developing and advanced countries. Given that the sample period covered only the 2006-2020 period (i.e., a total of 15 years) due to data availability issues, it is not possible to make a detailed quantitative analysis (such as regression estimations) for the case of individual countries. In other words, the available cross-country dataset does not allow conducting empirical analysis only for the case of Romania. Given this data restriction, we conducted a cross-country analysis in order to display the importance of corporate governance for stock market development and economic growth.

Before moving to the regression analysis, it would be informative to provide the pairwise cross-correlations of the corporate governance indicators with the variables of stock market development and economic growth. In this context, Table 3 presents the Pearson correlation coefficients for these variables. The results are presented in three panels, with the first panel showing the correlation coefficients for the full sample of 39 advanced and developing countries, while the second panel shows the results for the developing countries and the third panel shows the case of advanced countries. It is seen in the upper panel of Table 3 that GDP growth and stock market capitalisation (i.e., the value of listed companies in the stock markets as a ratio to GDP) had a positive and statistically significant (at the $5 \%$ level) correlation coefficient, with a value of 0.123 . While the size of the correlation coefficient was not very large, it implies that higher levels of stock market development were positively associated with higher economic growth rates. The table also shows that the stock market capitalisation variable had a positive and statistically significant (at the 5\% level) with the corporate governance indicator of the minority investor protection index, with a value of 0.468 . This value was relatively larger and implies that higher quality of corporate governance practices was positively associated with stock market development. Since, in return, stock market development was positively associated with economic growth, it can be argued that corporate governance can produce positive effects on the economic development of countries.

When the lower two panels of Table 3 were examined, some important differences in the cross-correlation coefficients were documented across developing and advanced countries. It was found that, in the case of the developing countries, the economic growth did not have a statistically significant correlation with any of the other variables. However, in the case of the stock market development, it had a positive and statistically significant correlation coefficient, with a value of 0.606 . This number is very large and indicates a strong positive association between corporate governance and stock market development. In addition, stock market development had positive and statistically significant correlation coefficients with the corporate governance dimensions of director liability, disclosure, ownership, and control. In the last panel of Table 3, the correlation coefficients for the advanced countries are presented. It can be seen that the GDP growth had a positive and statistically significant (at the 5\% level) regression coefficient with the stock market capitalization and the corporate governance score, with a value of 0.229 and a value of 0.153 , respectively. In addition, the stock market development had a positive and statistically 
significant regression coefficient with the corporate governance indicator (as measured by the protection of minority rights). Overall, these regression coefficients provide initial evidence for the two research hypotheses that corporate governance is positively associated with both stock market development and economic growth.

Table 3. Pairwise cross-correlations.

\begin{tabular}{|c|c|c|c|c|c|c|c|c|}
\hline \multicolumn{9}{|l|}{ Pairwise correlations-Full Sample } \\
\hline Variables & -1 & -2 & -3 & -4 & -5 & -6 & -7 & -8 \\
\hline (1) GDP Growth & 1 & & & & & & & \\
\hline (2) Stock Market Capitalization & 0.123 * & 1 & & & & & & \\
\hline (3) Protection of Minority Investors & 0.064 & 0.468 * & 1 & & & & & \\
\hline (4) Corporate Transparency & -0.021 & -0.024 & $0.415 *$ & 1 & & & & \\
\hline (5) Director Liability & 0.047 & $0.446^{*}$ & $0.540 *$ & $-0.242 *$ & 1 & & & \\
\hline (6) Disclosure & $0.130 *$ & $0.399 *$ & $0.705 *$ & $0.121 *$ & 0.249 * & 1 & & \\
\hline (7) Ownership and Control & -0.072 & -0.028 & $0.468 *$ & $0.315^{*}$ & 0.088 & -0.114 & 1 & \\
\hline (8) Shareholder Rights & -0.019 & $-0.232 *$ & $0.402 *$ & $0.322 *$ & $-0.132 *$ & -0.031 & $0.564 *$ & 1 \\
\hline
\end{tabular}

Pairwise correlations-Developing Countries

\begin{tabular}{ccccccccc}
\hline Variables & $\mathbf{- 1}$ & $\mathbf{- 2}$ & $\mathbf{- 3}$ & $\mathbf{- 4}$ & $\mathbf{- 5}$ & $\mathbf{- 6}$ & $\mathbf{- 7}$ & $\mathbf{- 8}$ \\
\hline (1) GDP Growth & 1 & & & & & & \\
(2) Stock Market Capitalization & -0.027 & 1 & & & & & \\
(3) Protection of Minority Investors & -0.006 & $0.606^{*}$ & 1 & & & & \\
(4) Corporate Transparency & 0.061 & -0.05 & $0.580^{*}$ & 1 & & & \\
(5) Director Liability & -0.034 & $0.627^{*}$ & $0.333^{*}$ & $-0.255^{*}$ & 1 & & \\
(6) Disclosure & 0.075 & $0.306^{*}$ & $0.708^{*}$ & 0.002 & $0.171^{*}$ & 1 & \\
(7) Ownership and Control & 0.043 & $0.489 *$ & $0.755^{*}$ & $0.646^{*}$ & 0.123 & 0.075 & 1 \\
(8) Shareholder Rights & 0.021 & 0.027 & $0.606^{*}$ & $0.574^{*}$ & $-0.278^{*}$ & 0.146 & $0.746^{*}$ & 1 \\
\hline
\end{tabular}

\begin{tabular}{|c|c|c|c|c|c|c|c|c|}
\hline \multicolumn{9}{|c|}{ Pairwise correlations-Advanced Countries } \\
\hline Variables & -1 & -2 & -3 & -4 & -5 & -6 & -7 & -8 \\
\hline (1) GDP Growth & 1 & & & & & & & \\
\hline (2) Stock Market Capitalization & $0.229 *$ & 1 & & & & & & \\
\hline (3) Protection of Minority Investors & 0.153 * & 0.381 * & 1 & & & & & \\
\hline (4) Corporate Transparency & -0.088 & 0.033 & 0.135 & 1 & & & & \\
\hline (5) Director Liability & $0.121 *$ & 0.308 * & 0.697 * & $-0.359 *$ & 1 & & & \\
\hline (6) Disclosure & $0.119 *$ & $0.475 *$ & 0.785 * & $0.462 *$ & $0.332 *$ & 1 & & \\
\hline (7) Ownership and Control & -0.126 & $-0.320 *$ & 0.239 * & -0.097 & 0.054 & $-0.201 *$ & 1 & \\
\hline (8) Shareholder Rights & -0.047 & $-0.451 *$ & 0.155 * & -0.173 * & -0.001 & $-0.170 *$ & 0.410 * & 1 \\
\hline
\end{tabular}

* shows significance at the 0.05 level.

The above findings are important for the case of Romania, as well. Figure 2a shows the evolution of the stock market capitalisation in Romania for the 2006-2020 period. It can be seen that, before the global financial crisis, the stock markets had a size of above $20 \%$ of GDP, while this ratio declined around 10\% of GDP after the global financial crisis and stagnated at these values. Given that the stock market development levels are larger in other countries (an average of around $70 \%$ in the developing countries and $80 \%$ in the advanced countries), the $10 \%$ can be considered too low for efficient capital markets in Romania. Hence, supporting stock market development can be an important policy area for the country. In return, the improvement of corporate governance practices can be an effective measure to support stock market development and economic growth in the country. Figure $2 \mathrm{~b}$ shows that, in the full sample, there is a positive association between stock market development and corporate governance scores. 


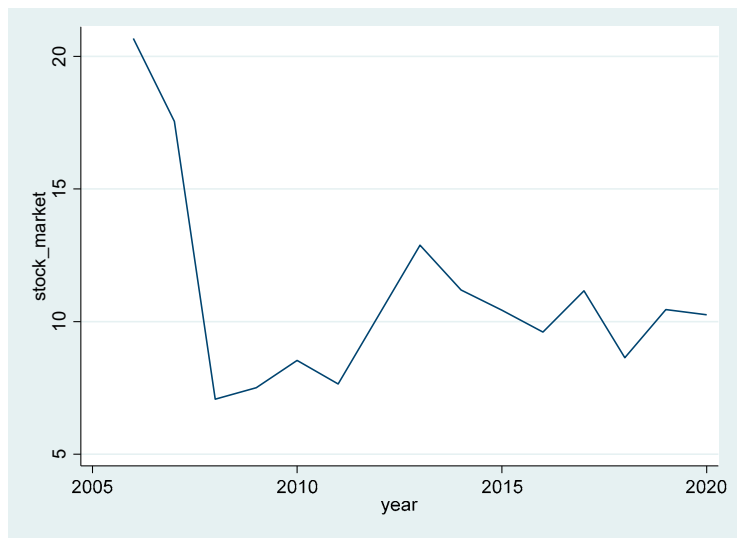

(a)

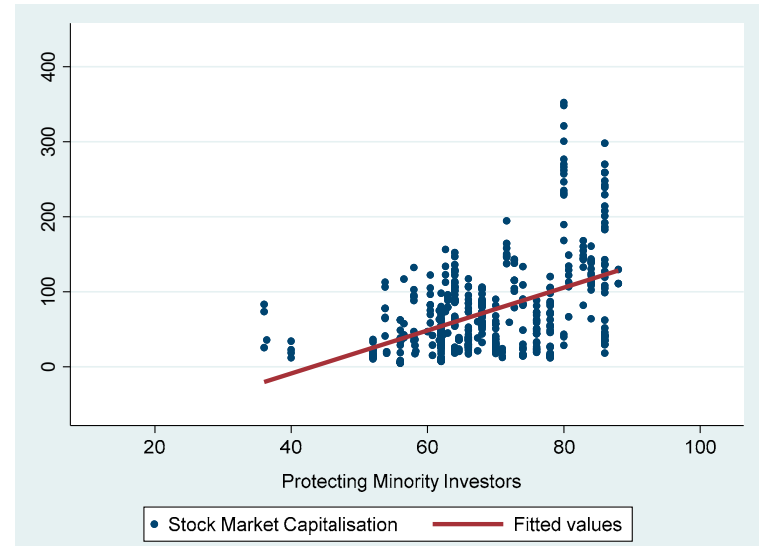

(b)

Figure 2. Stock markets and corporate governance. (a) stock market capitalisation/GDP (\%) Romania; (b) scatter plot between stock market capitalisation (\% of GDP) and the corporate governance index.

After presenting evidence from the analysis of cross-correlations and graphs, the final part of the empirical analysis presents the regression results. Specifically, Table 4 presents the OLS results and Table 5 provides the FE regression results. The presence of multicollinearity was tested for Model (3) using the VIF values, and it was found that the corresponding VIF values were less than 5 , thereby showing no presence of serious multicollinearity in the estimations. The results of the OLS regressions indicate that both stock market and corporate governance are statistically significant predictors of the economic growth in the full sample, as well as the sub-samples of advanced and developing countries.

Table 4. OLS regression results.

\begin{tabular}{|c|c|c|c|c|c|}
\hline & (1) & (2) & (3) & (4) & (5) \\
\hline Variables & Full Sample & Full Sample & Full Sample & Developing & Advanced \\
\hline \multirow[t]{2}{*}{ Investment } & $0.206^{* * *}$ & $0.266^{* * *}$ & $0.265^{* * *}$ & $0.370 * * *$ & $0.251^{* * *}$ \\
\hline & $(0.0326)$ & $(0.0362)$ & $(0.0369)$ & $(0.0728)$ & $(0.0510)$ \\
\hline \multirow[t]{2}{*}{ Savings } & $0.0636^{* *}$ & 0.0186 & 0.00460 & 0.0284 & -0.0174 \\
\hline & $(0.0253)$ & $(0.0243)$ & $(0.0236)$ & $(0.0430)$ & $(0.0293)$ \\
\hline \multirow[t]{2}{*}{ Trade } & 0.000665 & -0.000983 & -0.00427 & 0.00555 & $-0.0100 * *$ \\
\hline & $(0.00303)$ & $(0.00338)$ & $(0.00373)$ & $(0.00585)$ & $(0.00471)$ \\
\hline \multirow[t]{2}{*}{ FDI } & 0.0484 & 0.0444 & 0.0544 & -0.00899 & $0.0892 *$ \\
\hline & $(0.0305)$ & $(0.0346)$ & $(0.0341)$ & $(0.0144)$ & $(0.0481)$ \\
\hline \multirow[t]{2}{*}{ Credit } & $-0.00993^{* * *}$ & $-0.0210 * * *$ & $-0.0262 * * *$ & $-0.0237 * *$ & $-0.0321 * * *$ \\
\hline & $(0.00295)$ & $(0.00390)$ & $(0.00409)$ & $(0.00959)$ & $(0.00619)$ \\
\hline \multirow[t]{2}{*}{ Stock Markets } & & $0.0147^{* * *}$ & $0.0115^{* * *}$ & $0.0119 * *$ & $0.0172 * * *$ \\
\hline & & $(0.00294)$ & $(0.00320)$ & (0.00499) & $(0.00483)$ \\
\hline \multirow[t]{2}{*}{ Corporate Governance } & & & $0.0773 * * *$ & $0.0520 *$ & $0.0886^{* * *}$ \\
\hline & & & $(0.0196)$ & $(0.0308)$ & $(0.0249)$ \\
\hline Observations & 520 & 425 & 425 & 154 & 271 \\
\hline R-squared & 0.223 & 0.287 & 0.322 & 0.226 & 0.390 \\
\hline
\end{tabular}

Refers to the significance levels: ${ }^{* *} p<0.01,{ }^{* *} p<0.05,{ }^{*} p<0.1$.

Given that the FE model improves over the OLS model by incorporating the unobserved country effects, the results in Table 5 can be considered more robust. In addition, we conducted a Hausman test to see where the fixed-effects estimation was the preferred method over the random-effects estimation. In the full sample, it was found that increasing stock market development by $10 \%$ would lead to $0.22 \%$ in the growth rate while increasing the corporate governance index by 10 points would lead to a $1.2 \%$ increase in the economic growth rate. It can be seen that these sizes were economically very large as well. In the case of the OLS model, similar statistically significant effects were obtained for the developing countries, while these effects became statistically insignificant in the case of the FE model. Overall, these results were consistent with the findings in the literature 
which has found positive effects of better corporate governance on economic growth and development (Classens 2006; Claessens and Yurtoglu 2012). Namely, by improving their corporate governance codes and practices, the economic efficiency of the stock markets can increase. In return, improved business efficiency and stock market development support economic growth. These findings are also consistent with the micro-based studies that find positive performance effects of corporate governance for businesses (Aggarwal et al. 2007).

Table 5. Fixed-effects (FE) regression results.

\begin{tabular}{|c|c|c|c|c|c|}
\hline & (1) & (2) & (3) & (4) & (5) \\
\hline Variables & Full Sample & Full Sample & Full Sample & Developing & Advanced \\
\hline \multirow[t]{2}{*}{ Investment } & $0.239^{* * *}$ & $0.286^{* * *}$ & $0.338^{* * *}$ & $0.571^{* * *}$ & $0.225^{* * *}$ \\
\hline & $(0.0392)$ & $(0.0449)$ & $(0.0471)$ & $(0.0881)$ & $(0.0613)$ \\
\hline \multirow[t]{2}{*}{ Savings } & $0.243^{* * *}$ & $0.183^{* * *}$ & $0.151 * *$ & 0.0562 & $0.242^{* * *}$ \\
\hline & $(0.0530)$ & $(0.0585)$ & $(0.0586)$ & $(0.0975)$ & $(0.0829)$ \\
\hline \multirow[t]{2}{*}{ Trade } & $0.0238 * *$ & $0.0292 * *$ & $0.0267 * *$ & 0.0424 * & $0.0236^{*}$ \\
\hline & $(0.0111)$ & $(0.0119)$ & $(0.0118)$ & $(0.0241)$ & $(0.0128)$ \\
\hline \multirow[t]{2}{*}{ FDI } & $0.0641^{* * *}$ & $0.0556^{* * *}$ & $0.0534^{* * *}$ & -0.0148 & $0.0979 * * *$ \\
\hline & $(0.0133)$ & $(0.0154)$ & $(0.0152)$ & $(0.0247)$ & $(0.0192)$ \\
\hline \multirow[t]{2}{*}{ Credit } & $-0.0415^{* * *}$ & $-0.0499 * * *$ & $-0.0540^{* * *}$ & $-0.0516 *$ & $-0.0434^{* * *}$ \\
\hline & $(0.00939)$ & $(0.0103)$ & $(0.0103)$ & $(0.0264)$ & $(0.0114)$ \\
\hline \multirow[t]{2}{*}{ Stock Markets } & & $0.0205^{* * *}$ & $0.0221^{* * *}$ & 0.0160 & $0.0284^{* * *}$ \\
\hline & & $(0.00608)$ & $(0.00602)$ & $(0.0105)$ & $(0.00719)$ \\
\hline \multirow[t]{2}{*}{ Corporate Governance } & & & $0.116^{* * *}$ & 0.0380 & $0.124^{* * *}$ \\
\hline & & & $(0.0353)$ & $(0.0703)$ & $(0.0456)$ \\
\hline Observations & 520 & 425 & 425 & 154 & 271 \\
\hline R-squared & 0.315 & 0.361 & 0.378 & 0.288 & 0.497 \\
\hline Number of id & 39 & 35 & 35 & 12 & 23 \\
\hline Country FE & Yes & Yes & Yes & Yes & Yes \\
\hline
\end{tabular}

\section{Discussion and Conclusions}

This paper has examined the evolution of corporate governance performance in the case of Romania from a cross-country perspective. The literature shows that corporate governance is an important factor for the business efficiency, the development of stock markets, and the economic growth of countries (Classens 2006; Claessens and Yurtoglu 2012). There are various studies that examine the evolution of corporate governance in Romania, including cross-country perspectives (Badulescu 2008; Buşu 2015; Popescu et al. 2015; Tofan and Cigu 2020). However, these studies provide qualitative and descriptive accounts of the research topic. The present study complements the literature by producing a quantitative analysis of the cross-country corporate governance performance in the case of Romania. For this purpose, a specific set of corporate governance indicators from a large sample of 39 advanced and developing countries was collected for the 2006-2020 period. The data indicates that the corporate governance score of Romania stayed constant for the 20072020 period, while the average scores for the developing countries increased to a large extent. With reference to the corporate governance dimensions, a mixed picture emerged in the sense that Romania underperformed other developing countries in the case of the dimensions of director liability and ownership and control, while it outperformed them in the case of the dimensions of corporate transparency, disclosure, and shareholder rights. Another important result is that the stock market capitalisation as a share of GDP was around 10\% in Romania, which was significantly lower than the other countries (which had around $75 \%$ stock market capitalisation ratios). Hence, the stagnant corporate governance scores and the low development level of stock markets stand out as important business challenges for the country. The correlation and regression analyses indicate that improvement of corporate governance indicators can affect both the stock market development and economic growth positively. In conclusion, Romania can benefit greatly from the improvement of corporate governance codes and practices in the country.

In addition to the macroeconomic and development implications of the papers, the results also have managerial implications. A study by Aggarwal et al. (2007) shows that 
there can be important cross-country differences in the corporate governance quality and these differences are also reflected in the performance and valuation of companies. These findings, along with the above empirical results, imply that companies can benefit greatly from improving their corporate governance practices, such as transparency (through different policies, such as independent board members and audit committees), disclosure quality (through different strategies, such as financial reporting and investor relations), and shareholder rights. Given these benefits, the regulators can also revise the corporate governance codes and recommendations to follow the best practice examples in the world. While the paper produces important findings, it can still benefit from addressing some shortages and expanding the empirical analysis in future research. For example, the empirical methods can include other regression estimations, such as GMM and instrumental variable (IV) methods. In this way, the endogeneity issues between corporate governance, stock market development, and economic growth would be addressed more effectively. In addition, given that there can be major differences in the existing large cross-country sample, cluster analysis should be in the spirit of Vărzaru et al. (2021).

Author Contributions: Conceptualization, B.A.M. and D.D.; data curation, B.A.M. and D.D.; Formal analysis, B.A.M. and D.D.; Methodology, B.A.M. and D.D.; Resources, B.A.M. and D.D. All authors have read and agreed to the published version of the manuscript.

Funding: This research received no external funding.

Institutional Review Board Statement: Not applicable.

Informed Consent Statement: Not applicable.

Conflicts of Interest: The authors declare no conflict of interest.

\section{References}

Aggarwal, Reena, Isil Erel, René M. Stulz, and Rohan Williamson. 2007. Do US Firms Have the Best Corporate Governance? A Cross-Country Examination of the Relation between Corporate Governance and Shareholder Wealth. Fisher College of Business Working Paper No. 2006-03-006, ECGI - Finance Working Paper No. 145/2007, Charles A. Dice Center Working Paper No. 2006-25. Available online: https:/ / ssrn.com/abstract=954169 (accessed on 15 October 2021). [CrossRef]

Aguilera, Ruth V., and Gregory Jackson. 2010. Comparative and international corporate governance. Academy of Management Annals 4: 485-556. [CrossRef]

Badulescu, Alina. 2008. Corporate Governance In Romania (II-Considerations On Romania's Compliance On OECD Principles On Corporate Governance). Annals of Faculty of Economics 2: 571-75.

Baker, C. Richard, and Dwight M. Owsen. 2002. Increasing the role of auditing in corporate governance. Critical Perspectives on Accounting 13: 783-95. [CrossRef]

Barro, Robert J. 1991. Economic growth in a cross section of countries. The Quarterly Journal of Economics 106: 407-43. [CrossRef]

Barro, Robert J. 2003. Determinants of economic growth in a panel of countries. Annals of Economics and Finance 4: $231-74$.

Basco, Rodrigo, Giovanna Campopiano, Andrea Calabrò, and Sascha Kraus. 2019. They are not all the same! Investigating the effect of executive versus non-executive family board members on firm performance. Journal of Small Business Management 57: 637-57. [CrossRef]

Bebchuk, Lucian, Alma Cohen, and Allen Ferrell. 2009. What matters in corporate governance? The Review of Financial Studies 22: 783-827. [CrossRef]

Becht, Marco, Patrick Bolton, and Ailsa Röell. 2003. Corporate governance and control. Handbook of the Economics of Finance 1: 1-109.

Belloc, Filippo. 2012. Corporate governance and inovation: A survey. Journal of Economic Surveys 26: 835-64. [CrossRef]

Bhagat, Sanjai, and Brian Bolton. 2008. Corporate governance and firm performance. Journal of Corporate Finance 14: 257-73. [CrossRef]

Bhagat, Sanjai, and Brian Bolton. 2019. Corporate governance and firm performance: The sequel. Journal of Corporate Finance 58: 142-68. [CrossRef]

Buşu, Mihail. 2015. Corporate Governance Codes in Romania and European Union Countries. Revista de Management Comparat International 16: 119-28.

Cavaco, Sandra, Patricia Crifo, Antoine Rebérioux, and Gwenael Roudaut. 2017. Independent directors: Less informed but better selected than affiliated board members? Journal of Corporate Finance 43: 106-21. [CrossRef]

Chowdhury, Abdur, and George Mavrotas. 2006. FDI and growth: What causes what? World Economy 29: 9-19. [CrossRef]

Claessens, Stijn, and B. Burcin Yurtoglu. 2012. Corporate Governance and Development: An Update. Global Corporate Governance Network. Washington, DC: World Bank.

Claessens, Stijn, and B. Burcin Yurtoglu. 2013. Corporate governance in emerging markets: A survey. Emerging Markets Review 15: 1-33. [CrossRef] 
Classens, Stijn. 2006. Corporate governance and development. The World Bank Research Observer 21: 91-122. [CrossRef]

Cooray, Arusha. 2010. Do stock markets lead to economic growth? Journal of Policy Modeling 32: 448-60. [CrossRef]

Doidge, Craig, G. Andrew Karolyi, and René M. Stulz. 2007. Why do countries matter so much for corporate governance? Journal of Financial Economics 86: 1-39. [CrossRef]

Donaldson, Thomas. 2013. Corporate governance. International Encyclopedia of Ethics, 1-9. [CrossRef]

Elsayed, Khaled. 2007. Does CEO duality really affect corporate performance? Corporate Governance: An International Review 15: 1203-14. [CrossRef]

Feleagă, Niculae, Liliana Feleagă, Voicu Dan Dragomir, and Adrian Doru Bigioi. 2011. Corporate Governance in Emerging Economies: The Case of Romania. Theoretical and Applied Economics 18: 5-16.

Fernandes, Nuno. 2008. EC: Board compensation and firm performance: The role of "independent" board members. Journal of Multinational Financial Management 18: 30-44. [CrossRef]

Grosu, Maria. 2011. Codes and practices of implementation of corporate governance in Romania and results reporting. Annals of Faculty of Economics 1: 251-56.

Iwaisako, Tatsuro, and Koichi Futagami. 2013. Patent protection, capital accumulation, and economic growth. Economic Theory 52: 631-68. [CrossRef]

Khanna, Tarun, Joe Kogan, and Krishna Palepu. 2006. Globalization and similarities in corporate governance: A cross-country analysis. Review of Economics and Statistics 88: 69-90. [CrossRef]

Krause, Ryan, Matthew Semadeni, and Albert A. Cannella Jr. 2014. CEO duality: A review and research agenda. Journal of Management 40: 256-86. [CrossRef]

Larcker, David, and Brian Tayan. 2015. Corporate Governance Matters: A Closer Look at Organizational Choises and Their Consequences. London: Pearson Education.

Law, Siong Hook, and Nirvikar Singh. 2014. Does too much finance harm economic growth? Journal of Banking E Finance 41: 36-44.

Lee, Thomas A. 2007. Financial Reporting and Corporate Governance. Hoboken: John Wiley \& Sons.

Manolescu, Maria, Aureliana Geta Roman, and Mihaela Mocanu. 2011. Corporate governance in Romania: From regulation to implementation. Accounting and Management Information Systems 10: 4.

Mennicken, Andrea, and Michael Power. 2013. Auditing and Corporate Governance. In The Oxford Handbook of Corporate Governance. Oxford: Oxford University Press. [CrossRef]

Misangyi, Vilmos F., and Abhijith G. Acharya. 2014. Substitutes or complements? A configurational examination of corporate governance mechanisms. Academy of Management Journal 57: 1681-705. [CrossRef]

Mohan, Ramesh. 2006. Causal relationship between savings and economic growth in countries with different income levels. Economics Bulletin 5: 1-12.

OECD. 2021. OECD Corporate Governance Factbook. Available online: https://www.oecd.org/corporate/OECD-CorporateGovernance-Factbook.pdf (accessed on 27 September 2021).

Ong, Audra. 2018. Financial reporting and corporate governance: Bridging the divide. Journal of Management Research 18: 37-43.

Popescu, Gheorghe N., Veronica Adriana Popescu, and Cristina Raluca Popescu. 2015. Corporate Governance in Romania: Theories and Practices. In Corporate Governance and Corporate Social Responsibility: Emerging Markets Focus. Singapore: World Scientific Publishing Co. Pte. Ltd., chp. 14. pp. 375-401.

Sarchizian, Sergiu, and Veronica Popovici. 2019. Corporate Governance in Romania-Current Trends. Ovidius University Annals, Economic Sciences Series 19: 115-22.

Singh, Tarlok. 2010. Does international trade cause economic growth? A survey. The World Economy 33: 1517-64. [CrossRef]

Tihanyi, Laszlo, Scott Graffin, and Gerard George. 2014. Rethinking governance in management research. Academy of Management Journal 57: 1535-43. [CrossRef]

Tofan, Mihaela, and Elena Cigu. 2020. A view on Corporate Governance in Romania: Regulation and Effects. In Corporate Governance in Central Europe and Russia. Cham: Springer, pp. 177-97. [CrossRef]

Vărzaru, Anca Antoaneta, Claudiu George Bocean, and Michael Marian Nicolescu. 2021. Rethinking Corporate Responsibility and Sustainability in Light of Economic Performance. Sustainability 13: 2660. [CrossRef]

Wooldridge, Jeffrey M. 2010. Econometric Analysis of Cross Section and Panel Data. Cambridge: MIT Press.

World Bank. 2021. Doing Business. Available online: https:/ / databank.worldbank.org/source/doing-business (accessed on 22 September 2021).

Young, Steven. 2000. The increasing use of non-executive directors: Its impact on UK board structure and governance arangements. Journal of Business Finance \& Accounting 27: 1311-42. 